\title{
Rapid Microglial Response Around Amyloid Pathology after Systemic Anti-A $\beta$ Antibody Administration in PDAPP Mice
}

\author{
Jessica Koenigsknecht-Talboo, ${ }^{1,2}$ Melanie Meyer-Luehmann, ${ }^{3}$ Maia Parsadanian, ${ }^{1,2}$ Monica Garcia-Alloza, ${ }^{3}$ \\ Mary Beth Finn, ${ }^{1,2}$ Bradley T. Hyman, ${ }^{3}$ Brian J. Bacskai, ${ }^{3}$ and David M. Holtzman ${ }^{1,2}$ \\ ${ }^{1}$ Department of Neurology and ${ }^{2}$ Hope Center for Neurological Disorders, Washington University School of Medicine, St. Louis, Missouri 63110, and \\ ${ }^{3}$ Department of Neurology, Massachusetts General Hospital, Charlestown, Massachusetts 02129
}

\begin{abstract}
Aggregation of amyloid- $\beta(\mathrm{A} \beta)$ peptide in the brain in the form of neuritic plaques and cerebral amyloid angiopathy (CAA) is a key feature of Alzheimer's disease (AD). Microglial cells surround aggregated $\mathrm{A} \beta$ and are believed to play a role in AD pathogenesis. A therapy for $\mathrm{AD}$ that has entered clinical trials is the administration of anti- $\mathrm{A} \beta$ antibodies. One mechanism by which certain anti- $\mathrm{A} \beta$ antibodies have been proposed to exert their effects is via antibody-mediated microglial activation. Whether, when, or to what extent microglial activation occurs after systemic administration of anti- $\mathrm{A} \beta$ antibodies has not been fully assessed. We administered an anti-A $\beta$ antibody (m3D6) that binds aggregated A $\beta$ to PDAPP mice, an AD mouse model that was bred to contain fluorescent microglia. Three days after systemic administration of m3D6, there was a marked increase in both the number of microglial cells and processes per cell visualized in vivo by multiphoton microscopy. These changes required the Fc domain of m3D6 and were not observed with an antibody specific to soluble $\mathrm{A} \beta$. These findings demonstrate that some effects of antibodies that recognize aggregated $\mathrm{A} \beta$ are rapid, involve microglia, and provide insight into the mechanism of action of a specific passive immunotherapy for AD.
\end{abstract}

Key words: microglia; $\beta$-amyloid; passive immunization; Alzheimer's disease; neuritic plaques; cerebral amyloid angiopathy

\section{Introduction}

Alzheimer's disease (AD) is characterized by the presence of two pathological hallmarks, amyloid plaques and neurofibrillary tangles. Plaques consist primarily of extracellular deposits of amyloid- $\beta(\mathrm{A} \beta)$ in the brain parenchyma and in arterioles in the form of cerebral amyloid angiopathy (CAA) (Mandybur, 1975; Glenner et al., 1981; Vinters, 1987); tangles are composed primarily of aggregated, hyperphosphorylated forms of $\tau$ (Brion et al., 1985; Selkoe, 2001).

Another important feature of AD pathology are the inflammatory changes that occur, particularly involving microglia. In the $\mathrm{AD}$ brain as well as in $\mathrm{AD}$ mouse models, microglia cluster around plaques and CAA. It was recently demonstrated that microglial cells move toward newly formed plaques within $24 \mathrm{~h}$ of plaque formation (Meyer-Luehmann et al., 2008) as well as toward existing plaques over the course of $24 \mathrm{~h}$ (Bolmont et al., 2008). Plaque-associated microglia display an activated phenotype and are associated with an enhanced expression of immune cell surface markers and the production of proinflammatory cytokines and chemokines (Akiyama et al., 2000).

A promising therapy for $\mathrm{AD}$ that has entered human clinical trials is the peripheral administration of anti-A $\beta$ antibodies or

Received Aug. 30, 2008; revised Nov. 9, 2008; accepted Nov. 13, 2008.

This work was supported by National Institutes of Health Grants F32 AG029044 and NS32636, a Neuroscience Blueprint Center Core Grant P30 NS057105 to Washington University, and Eli Lilly and Co. We thank E. Nolley and K. Hyrc for technical assistance.

Correspondence should be addressed to David M. Holtzman, Washington University, Department of Neurology, 660 S. Euclid Avenue, Campus Box 8111, St. Louis, M0 63110. E-mail: holtzman@neuro.wustl.edu.

DOI:10.1523/JNEUROSCI.4147-08.2008

Copyright $\odot 2008$ Society for Neuroscience ～0270-6474/08/2814156-09\$15.00/0 passive immunization (Brody and Holtzman, 2008). Peripheral administration of certain anti-A $\beta$ antibodies has been shown to have potentially beneficial effects such as plaque clearance and cognitive improvement as well as toxic effects such as CAAassociated hemorrhage in animal models (Bard et al., 2000; Wilcock et al., 2004a,b, 2006; Vasilevko et al., 2007). One mechanism by which certain anti-A $\beta$ antibodies have been hypothesized to exert their beneficial as well as their toxic effects is via a small amount of the peripherally administered antibodies crossing the blood-brain barrier and binding to aggregated $\mathrm{A} \beta$, leading to antibody $\mathrm{Fc}$ domain-mediated microglial activation and $\mathrm{A} \beta$ phagocytosis (Bard et al., 2000; Wilcock et al., 2004a). Several studies have assessed the effects of anti-A $\beta$ antibodies administered directly into the CNS over days on microglial activation and A $\beta$ clearance (Bacskai et al., 2001; Bacskai et al., 2002; Pfeifer et al., 2002; Wilcock et al., 2003, 2004a,b, 2006; Racke et al., 2005; Burbach et al., 2007; Garcia-Alloza et al., 2007). These studies suggest that (1) antibodies to aggregated forms of A $\beta$ can clear parenchymal plaques by both Fc receptor dependent and independent mechanisms, (2) a marked increase in the number of microglia is observed with antibodies that bind aggregated $\mathrm{A} \beta$ with an intact Fc domain, (3) CAA is very difficult to clear, and (4) neuritic dystrophy can rapidly resolve. However, anti-A $\beta$ antibodies being administered to humans are being delivered outside the blood-brain barrier. Whether, when, or to what extent microglial activation in the CNS occurs after systemic administration of anti-A $\beta$ antibodies, especially soon after administration, has not been assessed. Herein, we examined the effects of peripherally administered anti-A $\beta$ antibodies in an $\mathrm{AD}$ mouse model that contains amyloid plaques and fluorescent microglia. 
We assessed baseline microglial behavior and whether the antibodies rapidly influenced microglial morphology in the brain and the properties of the antibodies required for the effects observed.

\section{Materials and Methods}

Animals. PDAPP ${ }^{+/-}$;CX3CR1/GFP ${ }^{+/-}$double-transgenic mice were generated by crossing $\mathrm{PDAPP}^{+/+}$mice (Games et al., 1995) with CX3CR1/GFP ${ }^{+/+}$mice (Jung et al., 2000). Double-transgenic mice used for these experiments were 4, 14, 18, or 22 months of age, as denoted for each experiment. The Institutional Review Board at Washington University approved all of the animal procedures used in this study.

Antibodies. m3D6 was a kind gift from Eli Lilly and Company. IgG2b was purchased from Zymed Laboratories/Invitrogen. Antibody mHJ5.1 was produced by using $A \beta$ peptide fragment $17-28$. This peptide was then used as an immunogen for production of a monoclonal antibody according to protocols established by the Washington University Hybridoma Center (http://pathology.wustl.edu/research/hybridoma.php). Fab fragments were generated from m3D6 using a Pierce kit. Briefly, purified IgG was dialyzed against a buffer containing $20 \mathrm{~mm}$ sodium phosphate and 10 mM EDTA, pH 7.0. It was then concentrated using a Pierce Slide-A-Lyzer dialysis cassette and Pierce Slide-A-Lyzer Concentrating Solution to $\sim 20 \mathrm{mg} / \mathrm{ml}$. Immobilized papain was washed twice in a glass test tube with a digestion buffer of $42 \mathrm{mg}$ of cysteine $\cdot \mathrm{HCl}$ in $12 \mathrm{ml}$ of phosphate buffer ( $\mathrm{pH} \mathrm{10}$ ) before resuspension in $0.5 \mathrm{ml}$ of digestion buffer and addition of concentrated IgG. The mixture was shaken for 45 $\min$ at $37^{\circ} \mathrm{C}$. The digest was separated from the immobilized papain and added to protein A-Sepharose and rotated for $45 \mathrm{~min}$ at room temperature. The digest was removed and contained the Fab portion of the IgG. An elution buffer was added to the protein A-Sepharose to remove any undigested IgG and bound Fc. All samples were concentrated and run on a 4-12\% Bis-tris gel (Invitrogen) for confirmation by size. For immunohistochemical analysis, rabbit anti-Iba-1 was from Wako, goat antirabbit Cy3 was from Jackson Immunoresarch, anti-CD45 was from Serotec, and the goat-anti-rat was from Vector Laboratories.

Antibody injection. Three days before cranial window surgery and imaging, mice were injected intraperitoneally with $500 \mu \mathrm{g}$ of m3D6, mHJ5.1, or IgG2b, or equimolar amounts of m3D6 Fab fragments.

Surgical procedure. The cranial window procedure was performed as described before (D'Amore et al., 2003; Brendza et al., 2005). Briefly, the mice were anesthetized with Avertin before being placed in a custom made stereotaxic device. After removing the hair and cleaning the skin on top of the head with Betadine (Purdue Pharma) and 70\% isopropanol, the skin was cut away from just posterior of the eyes to the base of the skull. A hole was carved in the skull, $\sim 7.5 \mathrm{~mm}$ in diameter, slightly anterior to bregma and slightly anterior to lambda. The carved portion of the skull was then removed to expose a fraction of the brain. The exposed brain region was then irrigated with PBS and packed with gel foam. Gel foam was removed and PBS was then added before the placement of an 8 $\mathrm{mm}$ glass coverslip. The glass coverslip was held into place with dental cement and superglue. A ring of paraffin was placed over the dental cement mixture to create a wall to hold immersion fluid for imaging.

In vivo brain imaging using two-photon microscopy. Approximately $18 \mathrm{~h}$ before imaging, mice were injected intraperitoneally with $10 \mathrm{mg} / \mathrm{kg}$ methoxy-XO4, which binds and labels amyloid in the brain. In cases in which angiograms were used to label vessels, the mice were injected with Texas Red dextran in a lateral tail vein minutes before imaging. Anesthetized mice with cranial windows were placed on the stage of a two-photon microscope (Zeiss LSM 510 Meta NLO system with a Coherent Chameleon Ti:Sa laser) while in a custom made stereotaxic device. Mice were imaged immediately after placement of the cranial windows. For simultaneous imaging of methoxy-XO4, green fluorescent protein (GFP), and Texas Red, an excitation wavelength of $800 \mathrm{~nm}$ was used. Fluorescence emission from amyloid bound methoxy-XO4, GFP, and Texas Red is collected in the ranges of $435-485 \mathrm{~nm}, 500-550 \mathrm{~nm}$, and 560-650 nm, respectively. Images were acquired as $512 \times 512$ arrays of 8 bit pixels in $\mathrm{z}$-series stacks. The fields of view were $\sim 230 \times 230 \mu \mathrm{m}$. Near amyloid pathology refers to microglial cells that were analyzed within the $230 \times$
$230 \mu \mathrm{m}$ field of view that contained amyloid pathology. Not near amyloid pathology refers to microglial cells that were analyzed in fields of view that did not contain amyloid deposition within the $230 \times 230 \mu \mathrm{m}$ field of view. Microglial cells that were completely in the field of view were studied for analysis.

Data analysis. Image stacks from each imaging session were processed and analyzed using both Zeiss and ImageJ software. Three-dimensional reconstruction of microglia from $z$-series stacks were made using maximum intensity projections. The number of processes extending from cell bodies as well as the number of cell bodies were counted in each field of view. All statistics were performed with GraphPad Prism (version 5.0).

Histology. Coronal sections $(50 \mu \mathrm{m})$ were cut on a freezing microtome. For immunohistochemistry, sections were blocked with $3 \%$ goat serum before overnight incubation with rabbit anti-Iba-1 antibody. Sections were then washed 3 times and incubated with a goat anti-rabbit Cy3 antibody. For immunohistochemistry of CD45, sections were incubated with an anti-CD45 antibody and detected with a goat anti-rat antibody.

Protein analysis. Three days before being killed, PDAPP ${ }^{+/-}$;CX3CR1/ $\mathrm{GFP}^{+/-}$mice were intraperitoneally injected with m3D6 $(500 \mu \mathrm{g})$ or PBS. The cortices were removed, weighed and homogenized in a $9 \times$ volume of $50 \mathrm{~mm}$ Tris- $\mathrm{HCl}$ buffer with $2 \mathrm{~mm}$ EDTA and protease inhibitors. The tissue homogenates were then sent to Rules-Based Medicine and analyzed in a multiplex assay.

\section{Results}

\section{Assessment of microglia in living PDAPP mice}

Recently, mice were generated in which GFP is inserted into the CX3CR1 gene (Jung et al., 2000). CX3CR1 is specifically expressed in microglia in the CNS, which can be imaged in vivo (Nimmerjahn et al., 2005). We crossed PDAPP mice to CX3CR1 mice to generate mice that developed amyloid plaques in the presence of fluorescent microglia. Real time in vivo images were taken to assess the morphology and behavior of microglial cells in the brains of PDAPP ${ }^{+/-}$; CX3CR1/GFP ${ }^{+/-}$mice. These doubletransgenic animals begin to develop amyloid pathology around 9 months of age whereas their microglial cells express GFP from birth onward. Through cranial windows, we observed vessels labeled with dextran, amyloid deposition labeled with methoxyXO4, and GFP-positive microglial cells (Fig. 1). Microglial cells in 14-17-month-old animals were compared between areas in the vicinity of CAA or parenchymal plaques and in fields of view that did not contain amyloid deposition. These animals were also compared with young PDAPP animals, 3.5 months old, before the deposition of amyloid as well as 5-month-old non-APP transgenic mice. The microglial cells in young APP-transgenic mice had smaller cell bodies than those observed in older APPtransgenic animals. Additionally, microglia in the young mice had longer processes than the microglia around plaques in the older mice. Microglial cells around amyloid pathology (within the $230 \times 230 \mu \mathrm{m}$ field of view) were noticeably different in appearance than those in areas of the brain distant from amyloid pathology (in a $230 \times 230 \mu \mathrm{m}$ field of view that did not contain pathology). These cells had fewer processes and larger cell bodies than cells distant from areas containing amyloid (Fig. 2).

Next, we assessed microglial dynamics around amyloid pathology. Images were taken of the same area 45-60 min apart. These images were compared with each other to detect changes in microglial process extensions and retractions that occurred over 45-60 min in the presence and absence of amyloid pathology and in mice of different ages. Microglial cells in young mice extended and retracted their processes significantly more than microglial cells in older mice (Fig. 3). The microglial cells immediately around amyloid pathology in older mice as well as areas distant from pathology appeared to be relatively stable and exhibited significantly less process movement compared with young mice. 


\section{Effects of antibody to aggregated $\mathrm{A} \boldsymbol{\beta}$ on microglial cells}

To determine the effects of a peripherally administered anti-A $\beta$ antibody on microglial cells, we injected $500 \mu \mathrm{g}$ of m3D6 intraperitoneally into 22-month-old $\mathrm{PDAPP}^{+/-}$;CX3CR $1 / \mathrm{GFP}^{+/-}$mice $3 \mathrm{~d}$ before imaging. m3D6 recognizes amino acids $1-5$ of the $A \beta$ peptide and can bind both aggregated and soluble $\mathrm{A} \beta$ (Bacskai et al., 2002; Cirrito et al., 2003). In vivo images were then taken of areas that contained CAA, parenchymal plaques, and areas with little to no amyloid pathology present immediately after placement of the cranial window. Microglial cells in m3D6-injected mice were compared with noninjected mice (Fig. 4). The m3D6injected animals contained significantly more detectable GFP-positive cells and these cells also had almost twice as many processes protruding from their cell bodies (Tables 1, 2; Fig. 4). These changes were very notable around parenchymal plaques, $\mathrm{CAA}$, and even in areas that did not contain methoxy-XO4 staining in the cortex. The changes seen in the GFP-positive cells were also seen with the microglial marker Iba- 1 , in sections stained at the end of the imaging sessions (Fig. 5). Cells in brain slices assessed after in vivo imaging stained with the microglial marker CD45 showed similar morphological changes seen with GFP and Iba-1 staining. However, with CD45, the colocalization was mostly with GFP-positive cells that were immediately around amyloid deposits (Fig. 6). This suggests that CD45 staining is relatively localized to "activated" CX3CR1-positive cells. There were no significant differences in dynamic microglial process movements between m3D6-injected and noninjected animals (data not shown). We also compared the levels of several growth factors, cytokines, and other proteins in the cortices of m3D6 versus vehicle-treated mice $3 \mathrm{~d}$ after injection and found that epidermal growth factor, haptoglobin, and MIP $1 \alpha$ were modestly and significantly lower in m3D6-treated mice (data not shown). This suggests that specific biochemical changes are occurring in conjunction with the cellular morphological changes observed.

\section{Microglial activation requires recognition of aggregated $\mathrm{A} \beta$ and the Fc domain}

We also injected 4-month-old mice, an age before amyloid deposition, with m3D6, to determine whether the observed effects were because of recognition of aggregated versus soluble forms of $\mathrm{A} \beta$ by the antibody. There was no significant difference between GFP-positive, microglial cell number or number of microglial processes when m3D6-injected and noninjected 4-month-old mice were compared (Table 3 ) suggesting the effects of m3D6 are because of the antibody binding aggregated forms of $A \beta$. Furthermore, we tested other antibodies to see whether they also affected microglial number or morphology. We injected $500 \mu \mathrm{g}$ of m3D6 into 18-month-old PDAPP ${ }^{+/-}$;CX3CR1/GFP ${ }^{+/-}$mice and compared the effects to mice injected with $500 \mu \mathrm{g}$ of mHJ5.1,
IgG2b, or equimolar amounts of m3D6 Fab fragments $3 \mathrm{~d}$ after intraperitoneal administration. $\mathrm{mHJ} 5.1$ is an antibody that recognizes amino acids $17-24$ of soluble $\mathrm{A} \beta$, but does not bind aggregated $A \beta$ in the form of plaques. IgG2b served as an isotype control to m3D6. As opposed to m3D6, treatment of mice with $\mathrm{mHJ} 5.1$ or IgG2b did not affect the number of GFP-positive microglia or alter their morphology (Fig. $7 A, B$ ). Fab fragments of m3D6 were also injected into 18-month-old mice to determine whether the full-length m3D6 antibody was needed to elicit the change in microglial cell number and morphology. Injection of m3D6 Fab fragments had no effect on GFP-positive microglial cell number or morphology suggesting that the presence of the $\mathrm{FC}_{\mathrm{C}}$ domain was required to elicit the microglial changes observed in m3D6-treated mice (Fig. 7 $A, B$ ).

\section{Discussion}

The amyloid hypothesis of $\mathrm{AD}$ postulates that the aggregation of $\mathrm{A} \beta$ results in a myriad of downstream events leading to the neurodegeneration that typifies AD (Selkoe, 2000). Therefore, studying the relationship between the potentially deleterious accumulation of $\mathrm{A} \beta$ and microglial cells, which invariably surround plaques, is important in understanding $\mathrm{AD}$ pathogenesis. We studied microglial cells before and after amyloid deposition. We found that microglial processes extended and retracted significantly more in younger than in older APP transgenic mice. Fur- 


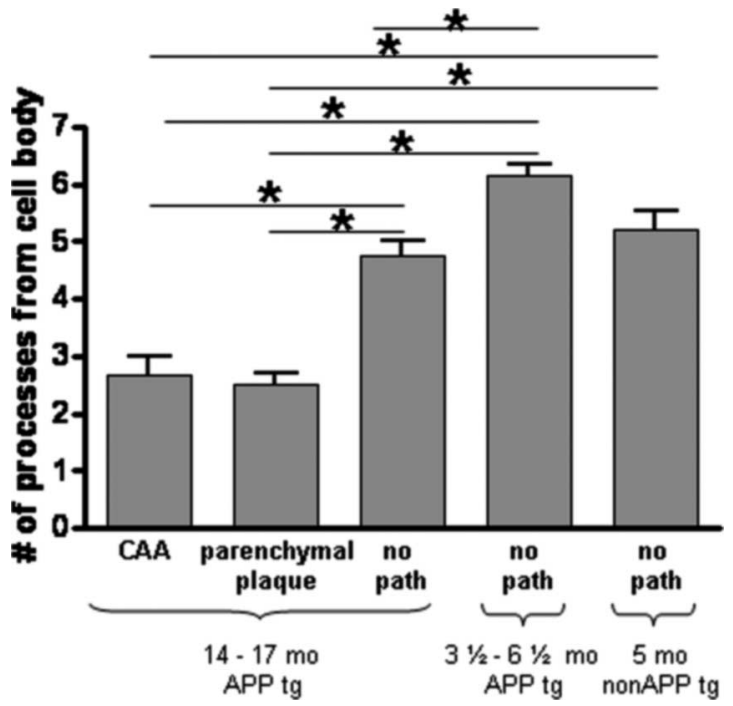

Figure 2. Decrease in the number of microglial processes around amyloid deposition. The number of processes extending from the cell body were counted in areas containing CAA, parenchymal amyloid plaques, and no amyloid pathology (no path). Microglia were compared in 14- to 17-month-old mice around CAA, parenchymal amyloid plaques, and in areas with no amyloid pathology as well as in 3.5- to 6.5 -month-old PDAPP ${ }^{+/-}$;CX3CR1/GFP ${ }^{+/-}$mice lacking amyloid pathology and 5-month-old PDAPP ${ }^{-1-} ; \mathrm{CX} \mathrm{CR} 1 / \mathrm{GFP}^{+/-}$mice. Five mice were studied per age group in APP transgenic mice, and six fields of view were imaged in each animal. Six fields of view were studied in two non-APP transgenic mice. Data are presented as the mean \pm SEM; ${ }^{*} p<0.001$.

thermore, the presence of amyloid pathology was associated with altered microglial morphology. We also demonstrated that microglia undergo rapid changes after systemic administration of a specific anti-A $\beta$ antibody. These alterations, an increase in the number of processes per cell and in cell number, were observed in older PDAPP mice but not in younger mice in which only soluble $\mathrm{A} \beta$ is present. Last, we demonstrated that this rapid microglial response required recognition of aggregated $A \beta$ and the Fc domain of the antibody.

Microglial cells consistently congregate around amyloid pathology in humans and animals. Microglia clustered around amyloid plaques, are classically activated, and release proinflammatory cytokines into the milieu (Akiyama et al., 2000; Combs et al., 2000; Combs et al., 2001). Inhibition of the complement cascade has been associated with an increase in $\mathrm{A} \beta$ pathology and degenerating neurons as well as an alteration in microglial responses (Wyss-Coray et al., 2002; Maier et al., 2008). Despite the fact that under certain conditions microglia have been shown to phagocytose $A \beta$ and have been implicated in $A \beta$ clearance (Bard et al., 2000; Wilcock et al., 2003, 2004a; Koenigsknecht and Landreth, 2004), microglial cells do not appear to efficiently or effectively clear amyloid in the $\mathrm{AD}$ brain. While it is clear that microglia cells play a role in $A \beta$-induced brain changes, the extent to which microglia play a positive versus negative role in the $\mathrm{AD}$ brain is not well understood. In this study, we demonstrate that microglial morphology is altered in the presence of amyloid pathology in APP transgenic mice in that the cells are less ramified, cell bodies are larger, and processes are shorter. We report a decrease in microglial process dynamics in older mice containing amyloid pathology whereas Bolmont et al. observed similar degrees of microglial process movement compared with non-APP transgenic mice (Bolmont et al., 2008). This difference may be attributable to several factors. Bolmont et al. used a different mouse model (Iba-1-GFP;APPPS1). This APPPS1 model begins
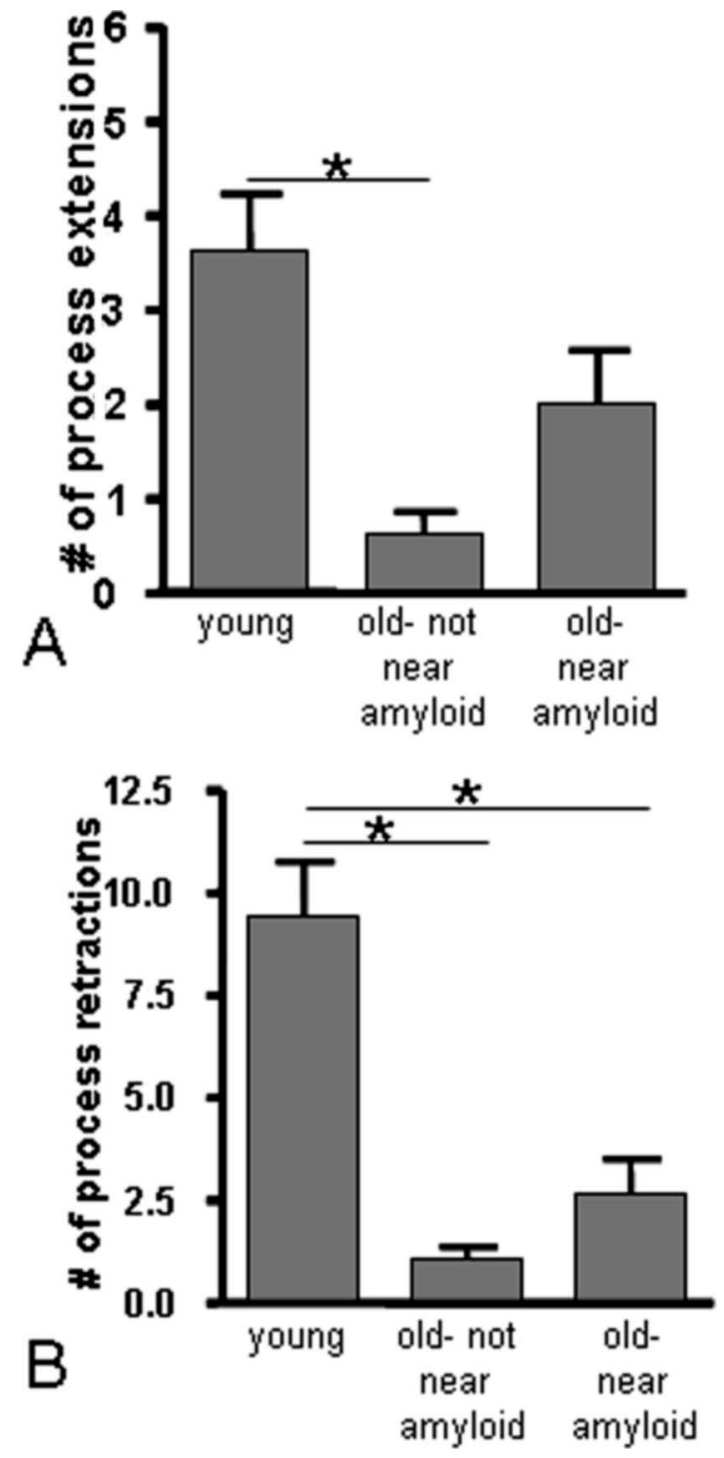

Figure 3. Decrease in microglial process movement in older PDAPP mice. The number of microglial process $(\boldsymbol{A})$ extensions and $(\boldsymbol{B})$ retractions were counted in young (3.5-to 6.5-monthold) and old (14- to 17-month-old) PDAPP ${ }^{+/-} ;$CX3CR1/GFP ${ }^{+/-}$mice near and distant from amyloid pathology. Five mice were studied per age group, and six fields of view were imaged in each animal. Data are presented as the mean \pm SEM; ${ }^{*} p<0.001$.

to develop amyloid pathology at $\sim 6$ weeks of age (Radde et al., 2006), and were imaged at 3-4 months. In our study the APPtransgenic mice developed amyloid pathology around 9 months of age and were imaged later. In addition, we imaged our mice immediately after placement of the cranial window, whereas the Bolmont group imaged their mice 1 week after cranial window surgery.

Currently, a promising AD therapeutic strategy is immunization. Animal model studies have shown that active immunization and passive immunization with certain anti-A $\beta$ antibodies results in decreased amyloid pathology and improved cognitive performance (Brody and Holtzman, 2008). To determine the effects of short term systemic treatment of a previously studied anti-A $\beta$ antibody (m3D6), a humanized version of which is now in phase III clinical trials in humans called Bapineuzumab (www.clinicaltrials. gov), on microglial cells, we intraperitoneally injected mice with m3D6 and imaged the mice $3 \mathrm{~d}$ later. We observed remarkable differences in the microglial cells between m3D6-injected and nonin- 

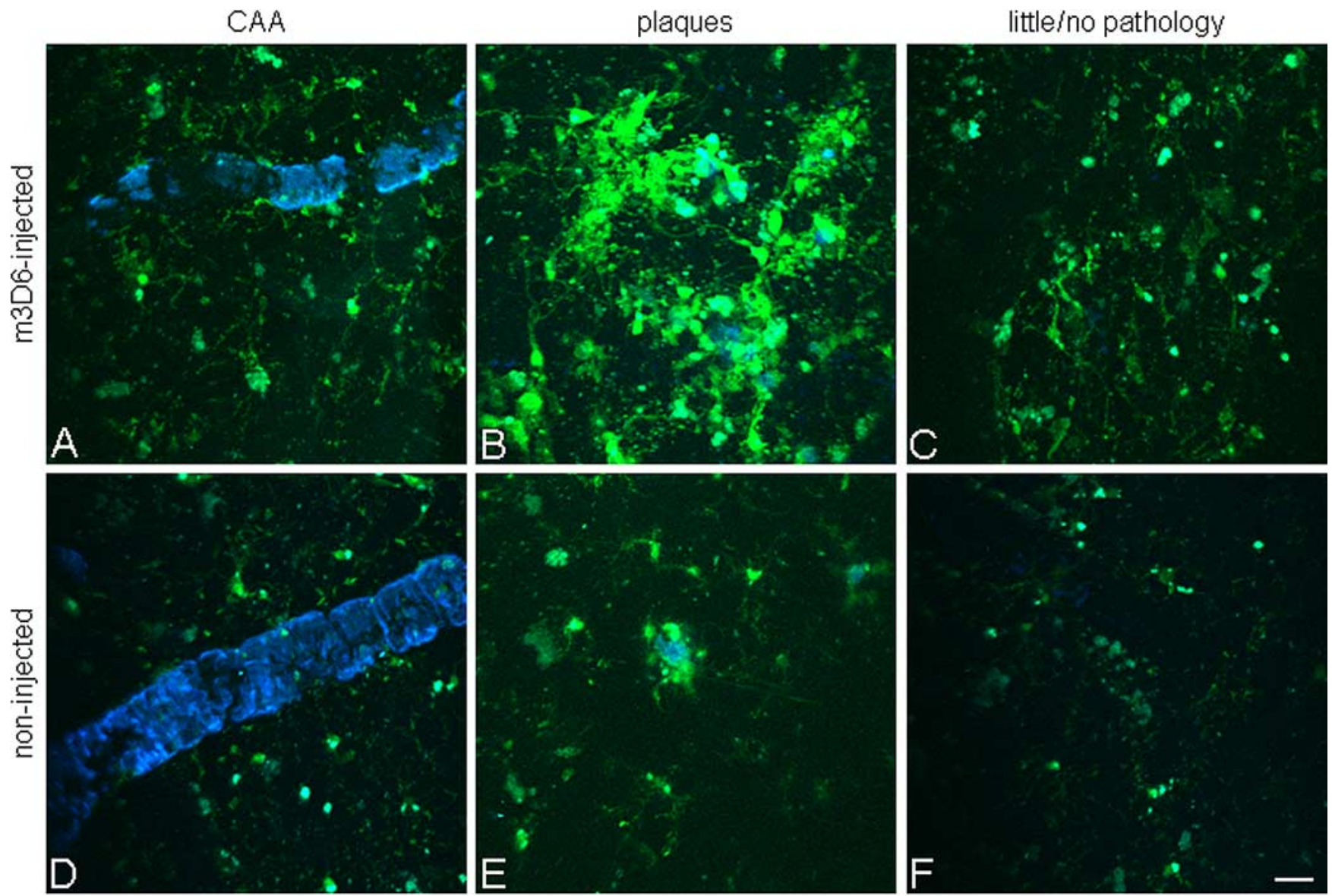

Figure 4. Peripheral $\mathrm{m} 3 \mathrm{D} 6$ administration results in marked morphological changes in microglia. Three-dimensional reconstructed z-series stack images taken of 22-month-old PDAPP ${ }^{+/-}$;CX3CR1/ $\mathrm{GFP}^{+/-}$mice injected with $500 \mu \mathrm{g}$ of m3D6 (A-C), an anti-A $\beta$ antibody, or not injected (D-F). GFP-labeled microglia are green. Fibrillar amyloid was labeled with methoxy-X04 (blue). Scale bar, $20 \mu \mathrm{m}$.

Table 1. Peripheral m3D6 injection increases the number of microglial processes per cell in 22-month-old PDAPP ${ }^{+/-} ; \mathrm{CX} \mathrm{CR} 1^{+/-}$mice

\begin{tabular}{llcll}
\hline Treatment & $\begin{array}{l}\text { All cortical } \\
\text { areas }\end{array}$ & CAA & Plaques & $\begin{array}{l}\text { Little/no } \\
\text { pathology }\end{array}$ \\
\hline m3D6 & $4.5 \pm 0.09$ & $44 \pm 0.15$ & $5.1 \pm 0.19$ & $4.7 \pm 0.18$ \\
Noninjected & $2.1 \pm 0.06$ & $1.9 \pm 0.10$ & $2.4 \pm 0.12$ & $2.0 \pm 0.13$ \\
\hline
\end{tabular}

The number of microglial processes were counted in three-dimensional reconstructed $z$-series stack images in 22-month-old PDAPP ${ }^{+-} ;$;X3CR1/GFP ${ }^{+/-}$mice injected with $500 \mu \mathrm{g}$ of m3D6 or in untreated mice. All cortical area samples were quantified, and the images were also divided into groups based on the presence of visualized pathology: in the vicinity of CAA, in the vicinity of parenchymal amyloid plaques, and in areas with little to no amyloid pathology. Four mice were studied per treatment group, and 6-10 fields of view were imaged in each animal. Data are presented as the mean \pm SEM. Peripheral m3D6 injection increases the number of microglial processes in 22 -month-old PDAPP ${ }^{+/-} ; \mathrm{CX}_{\mathrm{C}} \mathrm{CR} 1^{+/-}$mice.

Table 2. Peripheral m3D6 injection increases the number of microglial cells in 22-

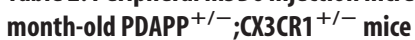

\begin{tabular}{lllll}
\hline Treatment & $\begin{array}{l}\text { All cortical } \\
\text { areas }\end{array}$ & CAA & Plaques & $\begin{array}{l}\text { Little/no } \\
\text { pathology }\end{array}$ \\
\hline m3D6 & $31.9 \pm 1.87$ & $30.2 \pm 2.54$ & $36.3 \pm 6.42$ & $30.2 \pm 3.04$ \\
Noninjected & $19.3 \pm 0.77$ & $19.7 \pm 1.09$ & $21.7 \pm 1.70$ & $16.9 \pm 1.11$ \\
\hline
\end{tabular}

The number of microglial cells were counted in three-dimensional reconstructed $z$-series stack images in 22-month-old $\mathrm{PDAPP}^{+/-}: \mathrm{CX} \mathrm{CR} 1 / \mathrm{GFP}^{+/-}$mice injected with $500 \mu \mathrm{g}$ of $\mathrm{m} 3 \mathrm{D} 6$ or in untreated mice. All cortical area samples were quantified, and the images were also divided into groups based on the presence of visualized pathology: in the vicinity of CAA, in the vicinity of parenchymal amyloid plaques, and in areas with little to no amyloid pathology. Four mice were studied per treatment group, and $6-10$ fields of view were imaged in each animal. Data are presented as mean \pm SEM. Peripheral m3D6 injection increases the number of microglial cells in 22-month-old PDAPPP ${ }^{+/-} ; \mathrm{CX} 3 \mathrm{CR} 1^{+/-}$mice.

jected mice. The microglial cells in the m3D6-injected mice contained significantly more processes per cell protruding from their cell somas than microglial cells in noninjected mice. There were also more microglia observed in the m3D6-injected mice than in the noninjected mice. These changes were observed in areas that contained amyloid pathology as well as areas that contained little to no pathology. Thus, m3D6 is able to initiate rapid changes in microglial cells, which may, in part, explain the results of previous studies that have observed clearance of amyloid after treatment with certain antibodies including m3D6 (Bard et al., 2000; Bacskai et al., 2001; Bacskai et al., 2002; Wilcock et al., 2003, 2004a,b, 2006; Burbach et al., 2007; Prada et al., 2007). Importantly, treatment with mHJ5.1, an antibody that binds soluble $\mathrm{A} \beta$ but not fibrillar $\mathrm{A} \beta$ did not induce the rapid changes in microglia. m3D6 binds both soluble and aggregated $\mathrm{A} \beta$. Injection of antibodies, including the chronic use of m3D6, has resulted in clearance of plaques compared with mice treated with various controls (Bard et al., 2000; Wilcock et al., 2003, 2004a,b; Schroeter et al., 2008). Furthermore, it has been demonstrated that placement of certain anti-A $\beta$ antibodies on the brain surface results in the rapid clearance of amyloid plaques, which was also accompanied by an increase in microglial cells around the area of antibody treatment (Bacskai et al., 2001; Prada et al., 2007). Although there is strong evidence for microglial-dependent amyloid clearance after CNS infusion of anti-A $\beta$ antibodies, there is also evidence for microglial-independent mechanisms. A two-phase mechanism for $A \beta$ clearance via $A \beta$ antibodies was introduced after intracranial administration of an $\mathrm{N}$-terminal $\mathrm{A} \beta$ antibody (Wilcock et al., 2003). The first, non-microglial-dependent, phase took place in the initial $24 \mathrm{~h}$. The second phase, between 1 and $3 \mathrm{~d}$ after antibody injection, revealed the presence of microglial activation and clearance of amyloid deposits. This result argues that multiple mechanisms, both dependent and independent of microglia, likely play a role in A $\beta$ plaque clearance. Wilcock et al. (2004a) have reported 
Iba-1
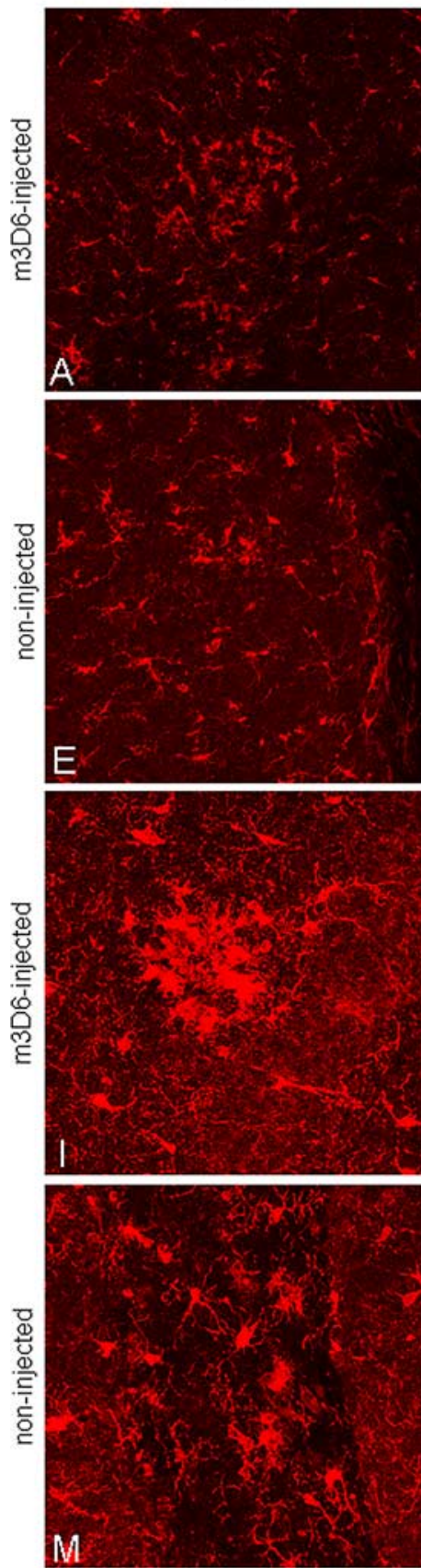

GFP
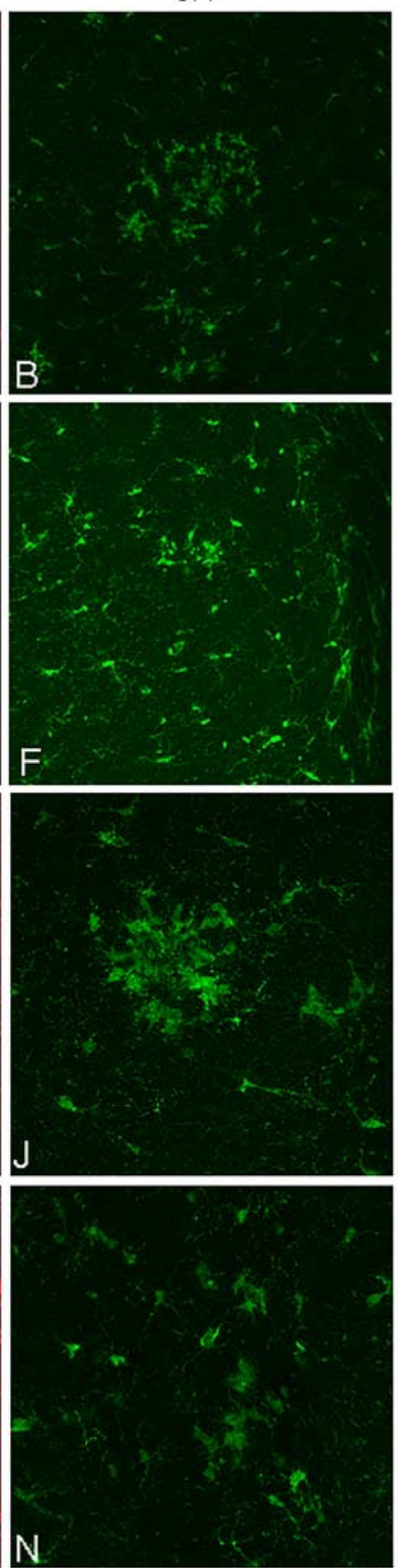

Methoxy-X04
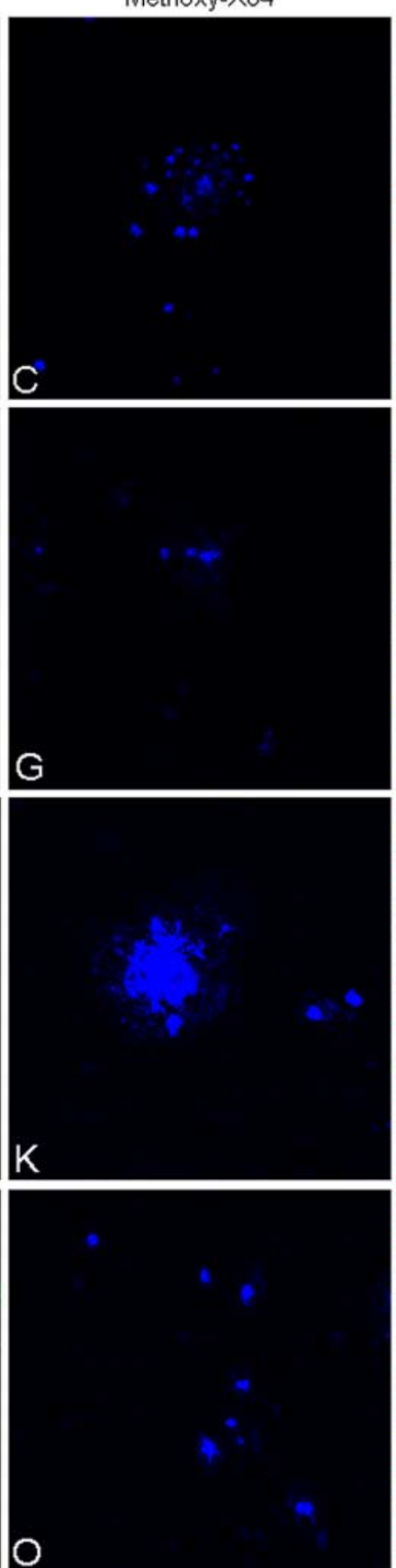
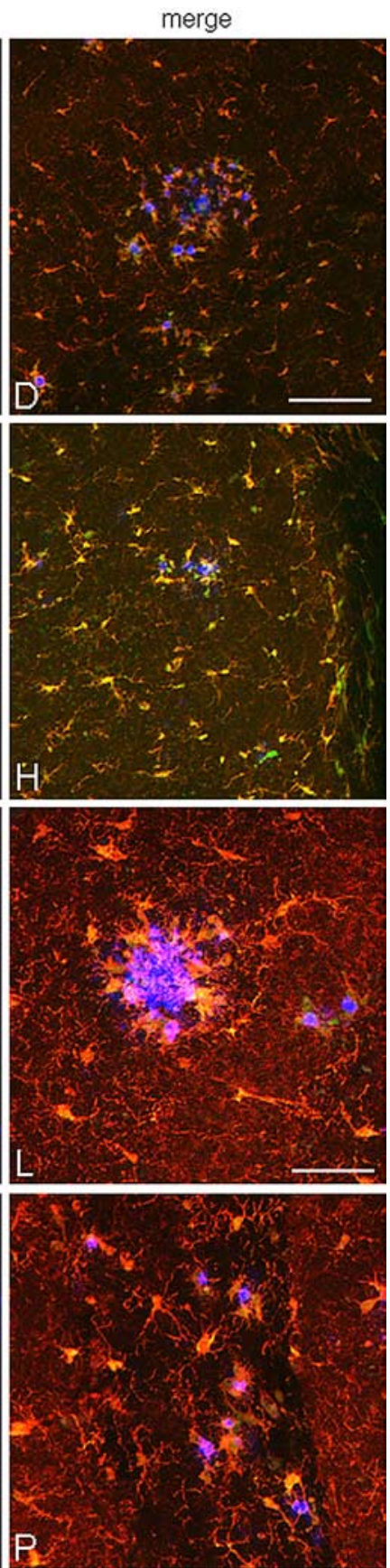

Figure 5. Iba-1 staining colocalizes with GFP-labeled microglia, and there is increased staining around plaques after m3D6 administration. Brain sections from 18-month-old PDAPP +/CX3CR1/GFP ${ }^{+/-}$mice were stained with Iba-1, and images were taken at low power $(\boldsymbol{A}-\boldsymbol{H})$ and high power $(\boldsymbol{I}-\boldsymbol{P})$. Iba-1-positive cells are in red $(\boldsymbol{A}, \boldsymbol{E}, \boldsymbol{I}, \boldsymbol{M})$, GFP labels CX3CR1-positive microglia $(\boldsymbol{B}, \boldsymbol{F}, \boldsymbol{J}, \boldsymbol{N})$, and methoxy-X04 labels aggregated amyloid in blue $(\boldsymbol{C}, \boldsymbol{G}, \boldsymbol{K}, \mathbf{O})$. Merged images are also shown $(\boldsymbol{D}, \boldsymbol{G}, \boldsymbol{L}, \boldsymbol{P})$. Scale bars are 100 and $50 \mu \mathrm{m}$, respectively, for low-power and high-power images.

clearance of amyloid deposits and behavioral improvement after chronic systemic treatment with anti- $\mathrm{A} \beta$ antibodies. Over months, they found that antibody enters the brain, binds deposits, and likely clears $\mathrm{A} \beta$ through $\mathrm{Fc}$ receptor-mediated phagocytosis. There are also potential side effects. It has been found that certain anti- $\mathrm{A} \beta$ antibodies increase microhemorrhages and macrohemorrhages associated with CAA (Pfeifer et al., 2002; Wilcock et al., 2004b; Racke et al., 2005). It is possible that an increase in activated microglia results in an increase in secretion of inflammatory cytokines, which may cause damage to vascular endothelium and smooth muscle cells thereby leading to hemorrhages. It is possible that the rapid changes in microglia after antibody treatment reported in this study may explain some of the positive responses (such as plaque clearance) as well as negative responses (such as vasogenic edema and CAAassociated hemorrhage) that have been observed in other anti- $\mathrm{A} \beta$ antibody studies.

The source of the increased number of microglial cells as the result of m3D6 treatment in our study is currently unknown. One possibility is that some of these cells come from an infiltration of cells into the brain from the periphery. There is evidence suggesting that some microglial cells are recruited to the brain parenchyma from the periphery by chemoattraction to surround amy- 


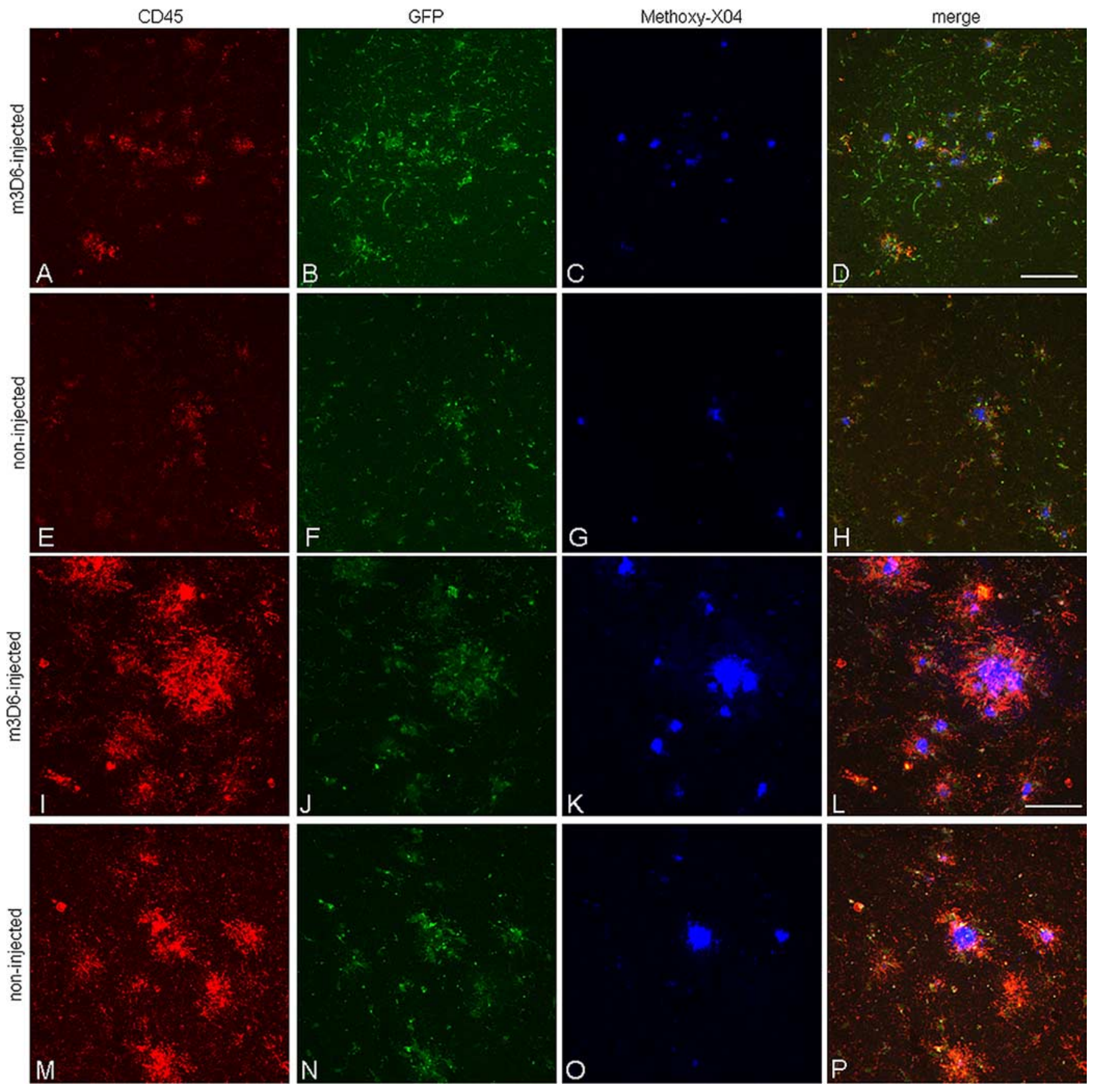

Figure 6. CD45 colocalizes with GFP-labeled microglia around amyloid pathology, and there is increased staining around plaques after m3D6 administration. Brain sections from 18 -month-old $\mathrm{PDAPP}^{+/-} ; \mathrm{CX} 3 \mathrm{CR} 1 / \mathrm{GFP}^{+/-}$mice were stained with $\mathrm{CD} 45$, and images were taken at low power $(\boldsymbol{A}-\boldsymbol{H})$ and high power $(\boldsymbol{I}-\boldsymbol{P})$. CD45-positive cells are in red $(\boldsymbol{A}, \boldsymbol{E}, \boldsymbol{I}, \boldsymbol{M}), \mathrm{GFP}$ labels $\mathrm{CX} 3 \mathrm{CR} 1$ positive microglia $(\boldsymbol{B}, \boldsymbol{F}, J, \boldsymbol{N})$, and methoxy-X04 labels aggregated amyloid in blue $(\boldsymbol{C}, \boldsymbol{G}, \boldsymbol{K}, \mathbf{O})$. Merged images are also shown $(\boldsymbol{D}, \boldsymbol{G}, \boldsymbol{L}, \boldsymbol{P})$. Scale bars are 100 and $50 \mu \mathrm{m}$, respectively, for low-power and high-power images.

Table 3. Peripheral m3D6 injection does not alter the number of microglial cells or the number of microglial processes per cell in 4-month-old PDAPP ${ }^{+/} ; \mathrm{CXXCR}^{+/-}$ mice

\begin{tabular}{lll}
\hline Treatment & No. of processes all cortical areas & No. of cells all cortical areas \\
\hline m3D6 & $3.5 \pm 0.07$ & $12.9 \pm 0.43$ \\
Noninjected & $3.6 \pm 0.12$ & $12.0 \pm 0.50$ \\
\hline
\end{tabular}

The number of microglial processes and the number of microglial cells were counted in three-dimensional reconstructed $z$-series stack images in 4-month-old PDAPP ${ }^{+/-} ; \mathrm{CX}^{-} \mathrm{CR} 1 / \mathrm{GFP}^{+/-}$mice injected with $500 \mu \mathrm{g}$ of m3D6 and in noninjected (untreated) mice. Four mice were studied per treatment group, and $6-10$ fields of view were imaged in each animal. Data are presented as mean \pm SEM. loid plaques (Simard et al., 2006). This infiltration of microglia was demonstrated in a model system that used bone-marrow chimeras that resulted from transplantation of lethally irradiated recipients. In a recent study, parabiosis rather than lethal irradiation was used, to produce chimeric mice (Ajami et al., 2007). This model did not result in the recruitment of peripherally derived microglia. However, in a set of animals that were lethally irradiated, there was recruitment of microglia from the periphery. In addition, it has been demonstrated that irradiation of mice while protecting their heads from irradiation does not result in microglia infiltration into the brain from the periphery after axotomy (Mildner et al., 2007). Thus, it has been argued that micro- 


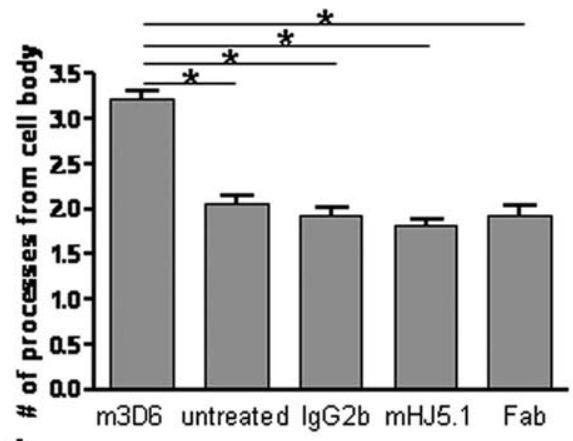

A

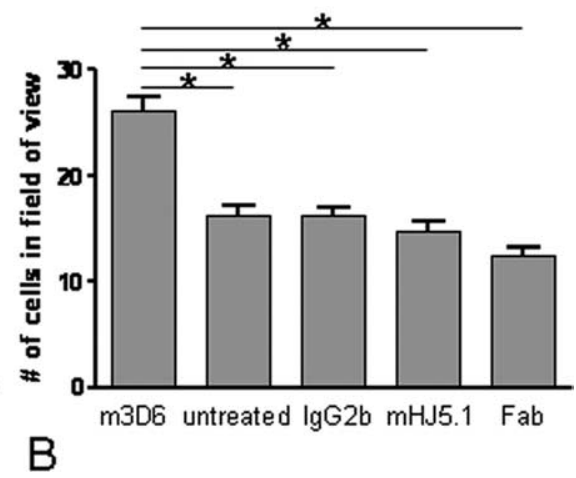

Figure 7. Microglial activation after antibody treatment requires recognition of aggregated $A \beta$ and the $F($ domain. The number of microglial processes $(\boldsymbol{A})$ and the number of microglial cells $(\boldsymbol{B})$ were counted in three-dimensional reconstructed $\mathrm{z}$-series stack images in 18-month-old PDAPP ${ }^{+/-} ; \mathrm{CX} \mathrm{CR} 1 / \mathrm{GFP}^{+/-}$mice not injected (untreated) or injected with $500 \mu \mathrm{g}$ of $\mathrm{m} 3 \mathrm{D} 6,500 \mu \mathrm{g}$ of $\mathrm{lgG} 2 \mathrm{~b}, 500 \mu \mathrm{g}$ of $\mathrm{mHJ} 5.1$, and $500 \mu \mathrm{g}$ of m3D6 Fab fragments. Four mice were studied per treatment group, and $6-10$ fields of view were imaged in each animal. Data are presented as the mean $\pm \mathrm{SEM} ;{ }^{*} p<0.001$.

glial recruitment in the lethally irradiated model was the result of a compromised blood-brain barrier or the result of a nonphysiological system. An alternative possibility for the increase in microglial cell number observed after antibody treatment is proliferation of resident cells in the brain parenchyma. For example, it has been shown that microglia proliferate around amyloid plaques (Bornemann et al., 2001). Some of our recent observations in the brains of PDAPP mice that we have examined, suggests that the increased microglial cells after m3D6 treatment is not solely the result of infiltration of cells from the periphery. We found that cells are not increased exclusively around venules, the location where immune cells enter the brain from the periphery in inflammatory disease models (Lassmann et al., 1981; Saida et al., 1981). It is likely that the increase in microglial cell number seen in mice treated with m3D6 is the result of the proliferation of resident cells as well as potentially infiltration of some cells from the periphery. Further studies to clarify this issue will be required.

In sum, the rapid changes in microglia observed could result in some of the beneficial changes seen in animals and possibly humans. These alterations in microglial cells may also be, in part, responsible for deleterious side effects such as edema and increased hemorrhages associated with CAA seen with some antibodies. It is possible that the side effects may be surmountable and avoided by utilization of antibodies lacking the property of induction of microglial activation.

\section{References}

Ajami B, Bennett JL, Krieger C, Tetzlaff W, Rossi FM (2007) Local selfrenewal can sustain CNS microglia maintenance and function throughout adult life. Nat Neurosci 10:1538-1543.

Akiyama H, Barger S, Barnum S, Bradt B, Bauer J, Cole GM, Cooper NR, Eikelenboom P, Emmerling M, Fiebich BL, Finch CE, Frautschy S, Griffin WS, Hampel H, Hull M, Landreth G, Lue L, Mrak R, Mackenzie IR, McGeer PL, et al. (2000) Inflammation and Alzheimer's disease. Neurobiol Aging 21:383-421.

Bacskai BJ, Kajdasz ST, Christie RH, Carter C, Games D, Seubert P, Schenk D, Hyman BT (2001) Imaging of amyloid- $\beta$ deposits in brains of living mice permits direct observation of clearance of plaques with immunotherapy. Nat Med 7:369-372.

Bacskai BJ, Kajdasz ST, McLellan ME, Games D, Seubert P, Schenk D, Hyman BT (2002) Non-Fc-mediated mechanisms are involved in clearance of amyloid- $\beta$ in vivo by immunotherapy. J Neurosci 22:7873-7878.

Bard F, Cannon C, Barbour R, Burke RL, Games D, Grajeda H, Guido T, Hu K, Huang J, Johnson-Wood K, Khan K, Kholodenko D, Lee M, Lieberburg I, Motter R, Nguyen M, Soriano F, Vasquez N, Weiss K, Welch B, et al. (2000) Peripherally administered antibodies against amyloid $\beta$-peptide enter the central nervous system and reduce pathology in a mouse model of Alzheimer disease. Nat Med 6:916-919.

Bolmont T, Haiss F, Eicke D, Radde R, Mathis CA, Klunk WE, Kohsaka S, Jucker M, Calhoun ME (2008) Dynamics of the microglial/amyloid interaction indicate a role in plaque maintenance. J Neurosci 28:4283-4292.

Bornemann KD, Wiederhold KH, Pauli C, Ermini F, Stalder M, Schnell L, Sommer B, Jucker M, Staufenbiel M (2001) A $\beta$-induced inflammatory processes in microglia cells of APP23 transgenic mice. Am J Pathol 158:63-73.

Brendza RP, Bacskai BJ, Cirrito JR, Simmons KA, Skoch JM, Klunk WE, Mathis CA, Bales KR, Paul SM, Hyman BT, Holtzman DM (2005) Anti-A $\beta$ antibody treatment promotes the rapid recovery of amyloid-associated neuritic dystrophy in PDAPP transgenic mice. J Clin Invest 115:428-433.

Brion JP, Couck AM, Passareiro E, FlamentDurand J (1985) Neurofibrillary tangles of Alzheimer's disease: an immunohistochemical study. J Submicrosc Cytol 17:89-96.

Brody DL, Holtzman DM (2008) Active and passive immunotherapy for neurodegenerative disorders. Annu Rev Neurosci 31:175-193.

Burbach GJ, Vlachos A, Ghebremedhin E, Del Turco D, Coomaraswamy J, Staufenbiel M, Jucker M, Deller T (2007) Vessel ultrastructure in APP23 transgenic mice after passive anti-A $\beta$ immunotherapy and subsequent intracerebral hemorrhage. Neurobiol Aging 28:202-212.

Cirrito JR, May PC, O’Dell MA, Taylor JW, Parsadanian M, Cramer JW, Audia JE, Nissen JS, Bales KR, Paul SM, DeMattos RB, Holtzman DM (2003) In vivo assessment of brain interstitial fluid with microdialysis reveals plaque-associated changes in amyloid- $\beta$ metabolism and half-life. J Neurosci 23:8844-8853.

Combs CK, Johnson DE, Karlo JC, Cannady SB, Landreth GE (2000) Inflammatory mechanisms in Alzheimer's disease: inhibition of $\beta$-amyloidstimulated proinflammatory responses and neurotoxicity by PPAR $\gamma$ agonists. J Neurosci 20:558-567.

Combs CK, Karlo JC, Kao SC, Landreth GE (2001) $\beta$-Amyloid stimulation of microglia and monocytes results in TNF $\alpha$-dependent expression of inducible nitric oxide synthase and neuronal apoptosis. J Neurosci 21:1179-1188.

D’Amore JD, Kajdasz ST, McLellan ME, Bacskai BJ, Stern EA, Hyman BT (2003) In vivo multiphoton imaging of a transgenic mouse model of Alzheimer disease reveals marked thioflavine-S-associated alterations in neurite trajectories. J Neuropathol Exp Neurol 62:137-145.

Games D, Adams D, Alessandrini R, Barbour R, Berthelette P, Blackwell C, Carr T, Clemens J, Donaldson T, Gillespie F, et al (1995) Alzheimer-type neuropathology in transgenic mice overexpressing V717F $\beta$-amyloid precursor protein. Nature 373:523-527.

Garcia-Alloza M, Ferrara BJ, Dodwell SA, Hickey GA, Hyman BT, Bacskai BJ (2007) A limited role for microglia in antibody mediated plaque clearance in APP mice. Neurobiol Dis 28:286-292.

Glenner GG, Henry JH, Fujihara S (1981) Congophilic angiopathy in the pathogenesis of Alzheimer's degeneration. Ann Pathol 1:120-129.

Jung S, Aliberti J, Graemmel P, Sunshine MJ, Kreutzberg GW, Sher A, Littman DR (2000) Analysis of fractalkine receptor CX(3)CR1 function by targeted deletion and green fluorescent protein reporter gene insertion. Mol Cell Biol 20:4106-4114.

Koenigsknecht J, Landreth G (2004) Microglial phagocytosis of fibrillar $\beta$-amyloid through a $\beta 1$ integrin-dependent mechanism. J Neurosci 24:9838-9846.

Lassmann H, Kitz K, Wisniewski HM (1981) Histogenesis of demyelinating lesions in the spinal cord of guinea pigs with chronic relapsing experimental allergic encephalomyelitis. J Neurol Sci 50:109-121.

Maier M, Peng Y, Jiang L, Seabrook TJ, Carroll MC, Lemere CA (2008) Complement C3 deficiency leads to accelerated amyloid $\beta$ plaque deposition and neurodegeneration and modulation of the microglia/macrophage phenotype in amyloid precursor protein transgenic mice. J Neurosci 28:6333-6341. 
Mandybur TI (1975) The incidence of cerebral amyloid angiopathy in Alzheimer's disease. Neurology 25:120-126.

Meyer-Luehmann M, Spires-Jones TL, Prada C, Garcia-Alloza M, de Calignon A, Rozkalne A, Koenigsknecht-Talboo J, Holtzman DM, Bacskai BJ, Hyman BT (2008) Rapid appearance and local toxicity of amyloid- $\beta$ plaques in a mouse model of Alzheimer's disease. Nature 451:720-724.

Mildner A, Schmidt H, Nitsche M, Merkler D, Hanisch UK, Mack M, Heikenwalder M, Bruck W, Priller J, Prinz M (2007) Microglia in the adult brain arise from Ly-6ChiCCR2+ monocytes only under defined host conditions. Nat Neurosci 10:1544-1553.

Nimmerjahn A, Kirchhoff F, Helmchen F (2005) Resting microglial cells are highly dynamic surveillants of brain parenchyma in vivo. Science 308:1314-1318.

Pfeifer M, Boncristiano S, Bondolfi L, Stalder A, Deller T, Staufenbiel M, Mathews PM, Jucker M (2002) Cerebral hemorrhage after passive anti-A $\beta$ immunotherapy. Science 298:1379.

Prada CM, Garcia-Alloza M, Betensky RA, Zhang-Nunes SX, Greenberg SM, Bacskai BJ, Frosch MP (2007) Antibody-mediated clearance of amyloid- $\beta$ peptide from cerebral amyloid angiopathy revealed by quantitative in vivo imaging. J Neurosci 27:1973-1980.

Racke MM, Boone LI, Hepburn DL, Parsadainian M, Bryan MT, Ness DK, Piroozi KS, Jordan WH, Brown DD, Hoffman WP, Holtzman DM, Bales KR, Gitter BD, May PC, Paul SM, DeMattos RB (2005) Exacerbation of cerebral amyloid angiopathy-associated microhemorrhage in amyloid precursor protein transgenic mice by immunotherapy is dependent on antibody recognition of deposited forms of amyloid $\beta$. J Neurosci 25:629-636.

Radde R, Bolmont T, Kaeser SA, Coomaraswamy J, Lindau D, Stoltze L, Calhoun ME, Jaggi F, Wolburg H, Gengler S, Haass C, Ghetti B, Czech C, Holscher C, Mathews PM, Jucker M (2006) A $\beta$ 42-driven cerebral amyloidosis in transgenic mice reveals early and robust pathology. EMBO Rep 7:940-946.

Saida T, Saida K, Silberberg DH, Brown MJ (1981) Experimental allergic neuritis induced by galactocerebroside. Ann Neurol 9 [Suppl]:87-101.

Schroeter S, Khan K, Barbour R, Doan M, Chen M, Guido T, Gill D, Basi G, Schenk D, Seubert P, Games D (2008) Immunotherapy reduces vascular amyloid- $\beta$ in PDAPP mice. J Neurosci 28:6787-6793.
Selkoe DJ (2000) Toward a comprehensive theory for Alzheimer's disease: hypothesis; Alzheimer's disease is caused by the cerebral accumulation and cytotoxicity of amyloid $\beta$-protein. Ann N Y Acad Sci 924:17-25.

Selkoe DJ (2001) Alzheimer's disease: genes, proteins, and therapy. Physiol Rev 81:741-766.

Simard AR, Soulet D, Gowing G, Julien JP, Rivest S (2006) Bone marrowderived microglia play a critical role in restricting senile plaque formation in Alzheimer's disease. Neuron 49:489-502.

Vasilevko V, Xu F, Previti ML, Van Nostrand WE, Cribbs DH (2007) Experimental investigation of antibody-mediated clearance mechanisms of amyloid- $\beta$ in CNS of Tg-SwDI transgenic mice. J Neurosci 27:13376-13383.

Vinters HV (1987) Cerebral amyloid angiopathy: a critical review. Stroke 18:311-324.

Wilcock DM, DiCarlo G, Henderson D, Jackson J, Clarke K, Ugen KE, Gordon MN, Morgan D (2003) Intracranially administered anti-A $\beta$ antibodies reduce $\beta$-amyloid deposition by mechanisms both independent of and associated with microglial activation. J Neurosci 23:3745-3751.

Wilcock DM, Rojiani A, Rosenthal A, Levkowitz G, Subbarao S, Alamed J, Wilson D, Wilson N, Freeman MJ, Gordon MN, Morgan D (2004a) Passive amyloid immunotherapy clears amyloid and transiently activates microglia in a transgenic mouse model of amyloid deposition. J Neurosci 24:6144-6151.

Wilcock DM, Rojiani A, Rosenthal A, Subbarao S, Freeman MJ, Gordon MN, Morgan D (2004b) Passive immunotherapy against A $\beta$ in aged APPtransgenic mice reverses cognitive deficits and depletes parenchymal amyloid deposits in spite of increased vascular amyloid and microhemorrhage. J Neuroinflammation 1:24.

Wilcock DM, Alamed J, Gottschall PE, Grimm J, Rosenthal A, Pons J, Ronan V, Symmonds K, Gordon MN, Morgan D (2006) Deglycosylated antiamyloid- $\beta$ antibodies eliminate cognitive deficits and reduce parenchymal amyloid with minimal vascular consequences in aged amyloid precursor protein transgenic mice. J Neurosci 26:5340-5346.

Wyss-Coray T, Yan F, Lin AH, Lambris JD, Alexander JJ, Quigg RJ, Masliah E (2002) Prominent neurodegeneration and increased plaque formation in complement-inhibited Alzheimer's mice. Proc Natl Acad Sci U S A 99:10837-10842. 